\title{
IMPLEMENTASI METODE BERMAIN PERAN PROFESIONAL DALAM PEMBELAJARAN KETERAMPILAN BERBICARA INDIVIDUAL MAHASISWA PROGDI PBSI UNIVERSITAS PGRI SEMARANG
}

\author{
Mukhlis, Siti Ulfiyani, dan Rawinda Fitrotul Mualafina \\ PBSI FPBS Universitas PGRI Semarang
}

\begin{abstract}
Abstrak
Secara langsung ataupun tidak, keterampilan berbicara menjadi satu keterampilan yang penting untuk dikuasai, terutama bagi mahasiswa Pendidikan Bahasa dan Sastra Indonesia. Berbagai upaya telah dilakukan untuk memaksimalkan penguasaan keterampilan berbicara oleh mahasiswa. Salah satu upaya yang sudah dilakukan dengan mencoba menerapkan berbagai metode yang sesuai. Metode yang kemudian direkomendasikan karena terbukti efektif dan menghasilkan keluaran yang baik adalah metode bermain peran profesional. Penelitian ini merupakan penelitian kualitatif. Subjek penelitian dipilih dengan teknik cluster random sampling sehingga terpilih kelas IA Program Studi PBSI. Data yang diperlukan diperoleh dengan teknik pengamatan, wawancara, dan dokumentasi. Penerapan metode bermain peran profesional dilaksanakan dalam tiga tahapan. Ketiga tahapan dimulai dari tahap prabicara, bicara, dan pascabicara. Dalam penerapannya digunakan instrumen pengamatan untuk melihat kemampuan berbicara, dengan dengan dua aspek penilaian, yaitu aspek kebahasan dan aspek nonkebahasaan. Dengan penerapan metode bermain peran profesional mahasiswa mencapai nilai rata-rata 77, 67. Artinya, metode bermain peran sesuai jika diterapkan untuk praktik berbicara individual.
\end{abstract}

Kata kunci: keterampilan berbicara, berbicara individual, bermain peran, kebahasaan, nonkebahasaan

\begin{abstract}
Speaking skill becomes an important skill, especially for Indonesian Education and Literature Education Student (PBSI). Several methods has been done to make that skill developed by the student. One of that methods is professional role playing that really effective and has been proved can increase the skill. This research was a qualitative one. The subject of this research choosen by cluster random sampling technic and PBSI student Class 1A as a sample of this research. The datas needed has been obtained from some technique, there are observation, interview, and documentation. The process of analysis has been done qualitatively. The application of the role playing method has been done for three steps. Those three steps was started from pre-speaking, speaking, and post-speaking. Observation was the instrument was used to know speaking skill with two rates aspects: linguistic aspect and nolinguistic aspect. By role playing application, student can reach 77,67\% as an average score. That result shows this role playing method was appropreiate to applied on individual speaking practice.
\end{abstract}

Keyword: speaking skill, individual speaking, role playing, linguistic, nonlinguistic

\section{PENDAHULUAN}

Dalam berbagai kesempatan pendampingan mahasiswa baik dalam rangka Kuliah Kerja Nyata ataupun Praktik Pengalaman Lapangan sering terdengar slentingan 'nanti, yang pidato kamu saja, ya, kamukan anak bahasa
Indonesia' atau 'masa anak bahasa Indonesia tidak bisa berbicara di depan umum' dari mahasiswa prodi lain. Seolah sudah menjadi keniscayaan bahwa mahasiswa Pendidikan Bahasa Indonesia perlu menguasai keterampilan berbicara di hadapan umum untuk berbagai kesempatan. 
$\begin{array}{clr}\text { Sebagai } & \text { upaya memberikan } \\ \text { kesempatan } & \text { mahasiswa } & \text { Prodi }\end{array}$ Pendidikan Bahasa dan Sastra Indonesia mengembangkan keterampilan berbicara, diadakanlah mata kuliah Berbicara. Mata kuliah Berbicara ini tidak hanya bertujuan menjadikan mahasiswa dapat berbicara, tetapi juga terampil berbicara. Untuk itu, pembelajaran keterampilan berbicara yang dilaksanakan perlu mencapai empat tujuan berikut:

1. membentuk kepekaan terhadap sumber ide;

2. membangun kemampuan menghasilkan ide;

3. melatih kemampuan berbicara untuk berbagai tujuan; dan

4. membina kreativitas berbicara, meliputi: menemukan, mengorganisasi, mengemas, dan menyampaikan ide (Abidin, 2013:131).

Tolok ukur atau indikator ketercapaian tujuan pembelajaran berbicara secara sederhana tampak pada penampilan mahasiswa saat praktik di depan kelas. Kelancaran penyampaian informasi menjadi ukuran mahasiswa menguasai atau tidak menguasai keterampilan berbicara. Meskipun mahasiswa sudah memiliki bekal kemampuan berbicara yang didapatkan dari bangku sekolah, bukan menjadi jaminan mahasiswa serta merta dapat tampil dengan baik. Persoalan ini disebabkan oleh beberapa hal, seperti:

1. mahasiswa belum mengenal secara dekat teman satu kelas yang berperan sebagai audiens sehingga muncul rasa malu yang berlebihan

2. mahasiswa memiliki keterbatasan pengalaman berbicara di hadapan umum

3. mahasiswa belum dapat memilih ide yang menarik untuk disampaikan di hadapan teman-temannya
4. jika topik sudah dimiliki, persoalan beralih pada belum mampunya mahasiswa dalam mengembangkan ide

5. kemampuan berbahasa yang dimiliki mahasiswa masih terbatas, yaitu yang berkaitan dengan pemilihan diksi yang tepat, dan

6. mahasiswa belum terbiasa berbicara untuk situasi yang bersifat formal.

Abidin (2013:141-143) memberikan masukan mengenai beberapa metode yang dapat digunakan untuk memaksimalkan keterampilan berbicara mahasiswa, khususnya berkaitan dengan penampilan mahasiswa saat praktik di depan kelas. Salah satu metode yang dapat diterapkan, yaitu metode bermain peran profesional. Metode bermain peran profesional merupakan metode pembelajaran yang menekankan kemampuan mahasiswa untuk tampil secara berkelompok untuk memerankan tokoh tertentu. Metode bermain peran profesional memiliki keunggulan yaitu memberikan kesempatan mahasiswa untuk mengekspresikan diri melalui peran yang dilakoni. Hal ini berarti dalam pembelajaran dengan metode bermain peran profesional, mahasiswa berkesempatan belajar melalui tindakan yang dilakukan atau learning by doing.

Metode bermain peran profesional sesuai dengan karakteristik mata kuliah Berbicara Individual yang memberikan mahasiswa kesempatan untuk tampil di depan kelas. Metode bermain peran profesional tidak sekadar memberikan mahasiswa kemampuan mengembangkan ide, tetapi juga mengembangkan kemampuan performa berbicara, seperti gestur yang tepat, pilihan kata yang sesuai, berekspresi sesuai ide yang disajikan, dan lain-lain.

Pada praktik berbicara individual konvensional, mahasiswa hanya mempraktikan salah satu jenis berbicara, seperti ceramah, pidato atau monolog. 
Praktik semacam itu tidak memberikan mahasiswa kesempatan untuk bekerja sama dengan peserta didik lain. Selain itu, tipe praktik semacam ini tidak memberikan pengalaman pengenalan berbagai situasi berbicara yang disesuaikan dengan situasi nyata yang ada di masyarakat. Dengan metode bermain peran profesional, mahasiswa diharapkan bekerja sama dalam praktik yang diselenggarakan dan memerankan tokoh yang dapat disesuaikan dengan tingkat penguasaan keterampilan berbicara yang dimiliki.

Sejumlah hal tersebut tidak dipilih untuk dilakukan dengan tanpa dasar. Dari sekian pengalaman yang ada, didapati mahasiswa masih banyak yang belum maksimal dalam pelaksanaan keterampilan berbicara di depan kelas. Kenyataan ini terlihat dalam presentasi di kelas, sampai dengan praktik mengajar. Komponen kebahasaan dan nonkebahasaan yang menjadi pendukung utama suksesnya keterampilan berbicara sering kali belum dapat terpenuhi dengan baik. Dari segi kebahasaan, misalnya, masih ditemukan kesalahan berbahasa dalam kaitannya dengan diksi dan penggunaan kalimat efektif secara lisan, termasuk pula intonasi yang kurang sesuai dengan suasana bicara yang tengah berlangsung. Adapun dari segi nonkebahasaan, terdapat kesalahan berbahasa dalam kaitanya dengan ekspresi dan gestur yang sering kali masih belum sempurna dan sesuai dengan ujaran yang diungkapkan.

Sebagai contoh, pada tahap percobaan, mahasiswa praktikan masih sering menggunaan intonasi yang terlalu rendah pada suasana bicara orasi, missalnya. Orasi yang pada dasarnya harus diujarkan dengan tegas dan resmi justru disampaikan dengan sedikit malu-malu dan tidak percaya diri. Pada tahap inilah kemudian segmen nonkebahasaan men- jadi penting, sebagaimana disebutkan sebelumnya, seperti ekspresi dan gestur. Dua hal ini melengkapi ujaran yang dituturkan secara lisan sehingga tuturan tersebut lebih dapat dipahami sebagai produk bicara. Ketika isi ujaran yang dituturkan adalah ujaran yang penuh bahagia, ekspresi cerah dan tersenyum menjadi pelengkap ujaran tadi.

Dengan sejumlah paparan tersebut, keterampilan berbicara mahasiswa PBSI, baik dari segi kebahasaan maupun nonkebahasaan, perlu ditinjau secara lebih lanjut. Dalam hal ini, metode yang digunakan adalah metode bermain peran profesional. Dengan metode ini, diharapkan keterampilan berbicara individual mahasiswa PBSI dapat tampak.

\section{METODE PENELITIAN}

Penelitian ini merupakan penelitian kualitatif. Metode kualitatif digunakan untuk data hasil penelitian berupa perilaku, persepsi, motivasi, tindakan dan lain-lain yang disajikan dengan kata-kata dan bahasa pada suatu konteks khusus yang alamiah dan memanfaatkan metode yang bersifat alamiah (Moleong 2005:6). Pada penelitian ini akan dideskripsikan implementasi metode bermain peran profesional dalam pembelajaran berbicara individual.

Dalam penelitian ini, peneliti menggunakan teknik cluster random sampling untuk penentuan sampel penelitian. Adapun sampel pada penelitian ini adalah mahasiswa Program Studi Pendidikan Bahasa dan Sastra Indonesia kelas 1A. Kelas 1A dipilih untuk mewakili empat kelas yang melaksanakan perkuliahan berbicara individual. Pemilihan kelas 1A didasarkan pada variasi kemampuan berbicara yang dimiliki mahasiswa di kelas 1A. 
Teknik pengumpulan data yang digunakan dalam penelitian ini adalah sebagai berikut:

\section{Teknik Pengamatan}

Teknik pengamatan yang digunakan dalam penelitian ini, yaitu teknik pengamatan partisipatif. Dengan dipergunakannya observasi partisipan ini, data yang diperoleh lebih lengkap, tajam, dan dapat digunakan sampai tahap mengetahui tingkat makna dari setiap perilaku yang tampak (Sugiyono, 2014:310). Dalam pelaksanaan pengamatan, peneliti melakukan perekaman berupa video. Teknik pengamatan partisipan digunakan untuk memperoleh data berupa deskripsi pelaksanaan metode bermain peran profesional yang dilakukan oleh dosen dan mahasiswa, termasuk di dalamnya kendala yang dihadapi dosen dan mahasiswa dalam pengimplementasian metode tersebut.

\section{Teknik wawancara}

Teknik wawancara digunakan untuk mengumpulkan data berupa persepsi atau pendapat dosen dan mahasiswa tentang pengalaman setelah penerapan metode bermain peran profesional dalam pembelajaran keterampilan berbicara. teknik wawancara yang digunakan ialah teknik wawancara mendalam. Dalam penelitian ini akan dilakukan wawancara terhadap enam belas mahasiswa. Enam belas mahasiswa mewakili delapan kelompok yang dibentuk dalam praktik berbicara dengan metode bermain peran profesional. Wawancara dilakukan setelah kelompok tampil. Wawancara dilakukan untuk mengetahui persepsi mahasiswa terhadap penerapan metode bermain peran termasuk kelebihan dan kesulitan yang dialami siswa saat praktik.

\section{Teknik dokumentasi}

Dokumen yang akan diteliti dalam penelitian ini yaitu rencana pelaksanaan perkuliahan yang dibuat oleh dosen, video pelaksanaan pembelajaran, dan hasil praktikum mahasiswa.

Data yang telah diperoleh dianalisis dengan langkah sebagai berikut:

1. Reduksi data hasil temuan berupa catatan pengamatan, video, rencana pelaksanaan perkuliahan, dan hasil praktikum mahasiswa. Dalam tahap reduksi data, peneliti merangkum, memilah hal pokok, menentukan yang pokok, dan membuang yang tidak berhubungan dengan penelitian.

2. Penyajian data dalam bentuk uraian, bagan, dan mendeskripsi hubungan antarkategori.

3. Penarikan kesimpulan dan verifikasi (Sugiyono, 2014:338-345).

\section{HASIL DAN PEMBAHASAN}

\section{PENERAPAN METODE BERMAIN PERAN PROFESIONAL DALAM PRAKTIK BERBICARA INDIVIDUAL}

Objek penelitian ialah mahasiswa kelas 1A Progdi Pendidikan Bahasa dan Sastra Indonesia. Pemilihan Mahasiswa 1A didasarkan pada pertimbangan hasil praktik mahasiswa dalam praktik level dasar yang belum seluruhnya mencapai hasil yang maksimal. Sebesar 58,14\% dari total keseluruhan mahasiswa di kelas 1A mendapatkan rerata hasil di bawah 70 .

Penelitian dilaksanakan mulai tanggal 10 November 2016 sampai dengan 8 Desember 2016. Jadwal penelitian menyesuaikan jadwal perkuliahan Berbicara Individual untuk kelas 1A yang dilaksanakan setiap Kamis, Pukul 13.00-14.40 WIB di ruang GP5 05 Universitas PGRI Semarang. Kegiatan penelitian disesuai- 
kan dengan rancangan pelaksanaan pembelajaran yang sudah disesuaikan dengan langkah penerapan metode yang dilaksanakan. Pembelajaran keterampilan berbicara individual dilaksanakan dalam tiga tahap. Penelitian dimulai dari tahap prabicara, bicara, dan pascabicara. Ketiga tahap tersebut dilaksanakan dalam lima kali pertemuan atau 500 menit, dengan rinciannya sebagai berikut:

Tabel 4.2 Jadwal Pelaksanaan Penelitian

\begin{tabular}{|c|c|c|}
\hline Hari/Tanggal & Waktu & Kegiatan \\
\hline $\begin{array}{l}\text { Kamis, } 10 \text { November } \\
2016\end{array}$ & $13.00-14.40$ & $\begin{array}{l}\text { Tahap prabicara } \\
\text { - Penjelasan teknis praktik } \\
\text { - Pembagian kelompok } \\
\text { - Diskusi kelompok }\end{array}$ \\
\hline $\begin{array}{l}\text { Kamis, } 17 \text { November } \\
2016\end{array}$ & $13.00-14.40$ & $\begin{array}{l}\text { Tahap Prabicara } \\
\text { - Pendalaman peran } \\
\text { - Pengembangan ide sesuai peran } \\
\text { - Penyusunan draf atau naskah }\end{array}$ \\
\hline $\begin{array}{lll}\text { Kamis, } & 24 & \text { November } \\
2016 & & \end{array}$ & $13.00-14.40$ & $\begin{array}{l}\text { Tahap Bicara } \\
\text { - Pelaksanaan praktik untuk tiga } \\
\text { kelompok }\end{array}$ \\
\hline Kamis, 1 Desember 2016 & $13.00-14.40$ & $\begin{array}{l}\text { Tahap Bicara } \\
\text { - pelaksanaan praktik untuk tiga } \\
\text { kelompok }\end{array}$ \\
\hline Kamis, 8 Desember 2016 & $13.00-14.40$ & $\begin{array}{l}\text { Tahap Bicara dan Pascabicara } \\
\text { - pelaksanaan praktik untuk dua } \\
\text { kelompok } \\
\text { - refleksi penampilan secara } \\
\text { global }\end{array}$ \\
\hline
\end{tabular}

\section{PELAKSANAAN PENELITIAN PENERAPAN METODE BERMAIN PERAN PROFESIONAL DALAM PRAKTIK BERBICARA.}

\section{Tahap Prabicara}

1. Pertemuan ke-1

Tahap prabicara dilaksanakan dalam dua kali pertemuan pada 10 November 2016 dan 17 November 2016. Pada pertemuan pertama mahasiswa mendapatkan pengetahuan tentang ruang lingkup praktik yang akan dilaksanakan dengan rincian berbagai kegiatan sebagai berikut.

a. Mahasiswa dibentuk menjadi delapan kelompok yang masingmasing terdiri atas 5-6 mahasiswa. b. Setiap kelompok mendiskusikan persitiwa yang akan dijadikan setting pelaksanaan praktik berbicara sekaligus membagi peran sesuai peristiwa yang dipilih. Dalam penentuan peristiwa, setiap kelompok menyesuaikan dengan konteks praktik yang memberikan kesempatan kepada setiap anggota kelompok untuk mengambil bagian, termasuk menyesuaikan peran dengan karakteristik tiap anggota. Di dalamnya dibicarakan pula sejumlah hal yang dibutuhkan dalam pelaksaan praktik kelompok. 
Tabel 4.3 Peristiwa dan Peran Mahasiswa Dalam Praktik Berbicara dengan Metode Bermain Peran Profesional

\begin{tabular}{|c|c|c|c|c|}
\hline No. & Kelompok & Peristiwa & Nama Anggota & Peran Anggota \\
\hline \multirow[t]{6}{*}{1} & Kelompok 1 & Sidang kasus & Putri Hagana & Jaksa pembela \\
\hline & & 'Jesika' & Yhoga Pratama & Hakim \\
\hline & & & Heni Safaatul & Jaksa penuntut umum \\
\hline & & & Izza Auliya M. & Pemilik cafe 'Oliver' \\
\hline & & & Selma Eka Novita & Saksi ahli \\
\hline & & & Regina Devi L. & Barista cafe 'Oliver' \\
\hline \multirow[t]{6}{*}{2} & Kelompok 2 & Reuni alumni & Tri Dewi Susanti & Pembawa acara \\
\hline & & $\begin{array}{lll}\text { SMA } & \mathrm{N}\end{array}$ & Auliya Yasmin & Ketua panitia \\
\hline & & Semarang & Hendra Riski & Kepala sekolah \\
\hline & & tahun angkatan & Retno Wahyu S. & Perwakilan alumni \\
\hline & & $2013 / 2014$ & Tri Cahya C. & Pengisi acara \\
\hline & & & Ristia Rizqy N.I. & Rohaniawan \\
\hline \multirow[t]{6}{*}{3} & Kelompok 3 & Malam puncak & Ariana Herawati & Ketua PKK \\
\hline & & peringatan & Danu Pratrisno & Kepala desa \\
\hline & & HUT RI ke-71 & Eko Vendy N. & Ketua panitia \\
\hline & & Kelurahan & Pegi Okta Triana & Pembaca doa \\
\hline & & Sendangmulyo & Weny Febriana A. & Pembawa acara \\
\hline & & & Awanda Aprilia & Pemenang lomba \\
\hline \multirow[t]{5}{*}{4} & Kelompok 4 & Paparan visi- & Fahmadin A. & Presiden BEM UPGRIS \\
\hline & & misi dan & Winda Rahmawati & Calon Presiden BEM 1 \\
\hline & & program kerja & Aulia Shery & Calon Presiden BEM 2 \\
\hline & & calon presiden & Puji Lestari & Pembawa acara \\
\hline & & $\begin{array}{l}\text { BEM UPGRIS } \\
\text { periode } \\
2017 / 2018\end{array}$ & Izza Fadlilatul M. & Calon Presiden BEM 3 \\
\hline \multirow[t]{5}{*}{5} & Kelompok 5 & Pemilihan & Raya Fitra D. & Kandidat 1 \\
\hline & & Ketua Hima & Dian Widi Astuti & Kandidat 2 \\
\hline & & PBSI UPGRIS & Reno Septa Budi L. & Ketua Hima PBSI \\
\hline & & periode & Sofi Lailatu R. & Kaprogdi PBSI \\
\hline & & $2016 / 2017$ & Indri Syaraswati & Pembawa acara \\
\hline \multirow[t]{5}{*}{6} & Kelompok 6 & Peringatan Isra & Azis Pijar & Kepala sekolah \\
\hline & & Mi'raj di SMA & Novita Nur $\mathrm{H}$. & Pembawa acara \\
\hline & & Pondok & Reni S. & Ketua panitia \\
\hline & & Modern & Miftah & Pendakwah \\
\hline & & Selamat & Atika Tiaratama & Pembaca doa \\
\hline \multirow[t]{5}{*}{7} & Kelompok 7 & Pentas seni & Ryan Al Farizi & Peserta 1 \\
\hline & & dalam rangka & Inayah Isnaini $\mathrm{F}$. & Ketua panitia \\
\hline & & penglepasan & Imas Saffanatul A. & Pembawa acara \\
\hline & & siswa SMA N 1 & Nita Aditia & Peserta 2 \\
\hline & & Kendal & Santinuk & Pembawa acara \\
\hline \multirow[t]{4}{*}{8} & Kelompok 8 & Lomba Pidato & Khuzzalatifah & Ketua panitia \\
\hline & & tingkat & Yeni Rosa D. & Kaprogdi PBSI \\
\hline & & SMA/SMK/M & Rizki Ramadhani & Rohaniawan \\
\hline & & A se-Semarang & Anis Safitri & Ketua Hima \\
\hline
\end{tabular}




\begin{tabular}{llll}
\hline oleh & Hima & Umy Khalifah & Pembawa acara \\
& PBSI FPBS & & \\
UPGRIS & & \\
\hline
\end{tabular}

2. Pertemuan ke-2

Pada pertemuan kedua tahap prabicara yang dilaksanakan pada 17 November 2016, mahasiswa menyusun naskah berbicara sesuai peran yang akan dimainkan berdasarkan hasil diskusi kelompok. Pada pertemuan tersebut, mahasiswa sudah membawa sejumlah data yang akan digunakan. Untuk itu, secara individual mahasiswa diberi kesempatan untuk mengekplorasi peran yang akan dimainkan sekaligus brainstroming di luar jam pembelajaran. Eksplorasi yang dilakukan meliputi:

a. mencari informasi tentang peran yang akan dimainkan

b. mencari referensi yang sesuai dengan tema peristiwa yang akan ditampilkan, yang akan digunakan untuk menyusun naskah atau teks berbicara.

Mahasiswa secara individual membuat rancangan teks pembicaraan yang dikembangkan menjadi naskah berbicara. Selain itu, mahasiswa juga mendapatkan bimbingan dari dosen berkaitan dengan isi naskah yang dikembangkan. Langkah terakhir dari tahap prabicara yang dilakukan adalah berlatih menampilkan peristiwa secara mandiri di luar jam pembelajaran untuk memastikan semua anggota kelompok siap tampil.

\section{Tahap Bicara}

Setiap kelompok menampilkan peristiwa pilihan dalam waktu 30 menit setelah sebelumnya mengatur ruang sesuai kebutuhan praktik. Mahasiswa menampilkan peristiwa dengan properti yang disiapkan secara mandiri.
Mahasiswa nonanggota kelompok yang tampil, berpartisipasi sebagai audiens.

Berdasar pada proses penerapan metode bermain peran profesional dalam pembelajaran keterampilan berbicara individual terhadap mahasiswa Progdi PBSI, ditemukan sejumlah hasil dari penelitian ini. Hasil ini diperoleh dari isian angket pengamatan pada aspek keterampilan berbicara individual sebagai instrumen penelitian yang digunakan. Pada penialaian ini, terdapat dua aspek yang dinilai, yaitu aspek kebahasaan dan aspek nonkebahasaan. Aspek kebahasaan yang dimaksud meliputi 1) ketepatan pengucapan vokal dan konsonan; 2) ketepatan intonasi, nada, dan irama; 3) pilihan kata; dan 4) ketepatan sasaran pembicaraan. Aspek nonkebahasaan, dalam hal ini, meliputi 1) keberanian; 2) kontak mata dan ekspresi; 3) penguasaan topik; 4) kelancaran penyampaian; 5) keterbukaan; dan 6) penalaran.

Tahapan yang dilakukan dalam proses pemerolehan hasil penelitian ini adalah dengan melakukan uji banding satu sampel.

1. Uji Banding Satu Sampel

Uji banding satu sampel dilakukan untuk mengetahui ketercapaian nilai 70 melalui penggunaan metode bermain peran profesional pada keterampilan berbicara individual mahasiswa Progdi PBSI. Dalam pengujian digunakan bantuan SPSS versi 16.0.

a. Pengujian persyaratan: variabel yang diselidiki adalah keterampilan berbicara individual mahasiswa Progdi PBSI. Variabel tersebut diperoleh melalui pengamatan (observasi) sehingga hasilnya 
berbentuk data kualitatif. Namun oleh peneliti data tersebut disimbolkan menjadi data numerik. Jadi jenis data dalam penelitian ini adalah ordinal.

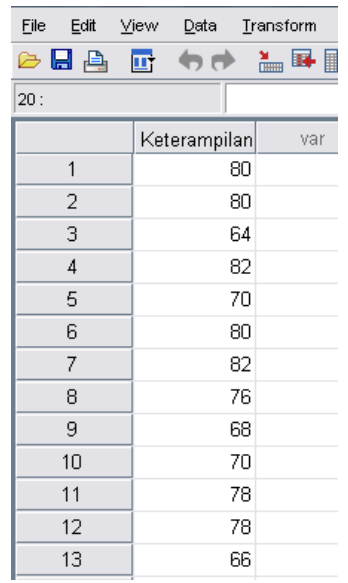

NPar Tests

\begin{tabular}{|ll|r|}
\hline \multicolumn{2}{|c|}{ One-Sample Kolmogorov-Smirnov Test } \\
\hline & & $\begin{array}{c}\text { Keterampilan } \\
\text { Berbicara } \\
\text { Individual }\end{array}$ \\
\hline N & & 43 \\
Normal Parameters ${ }^{\text {a }}$ & Mean & 77.67 \\
& Std. Deviation & 9.990 \\
Most Extreme Differences & Absolute & .118 \\
& Positive & .081 \\
& Negative & -.118 \\
Kolmogorov-Smirnov Z & & .771 \\
Asymp. Sig. (2-tailed) & & .591 \\
\hline
\end{tabular}

Output 4.1 Hasil Uji Banding Satu Sampel

Interpretasi pembacaan output untuk proses uji banding satu sampel.

a. Bentuk hipotesis uji banding satu sampel

$\mathrm{H}_{0}: \mu=70$

$\mathrm{H}_{1}: \mu \neq 70$

b. Analisis hasil: pada output di atas tampak nilai sig $=0,591=59,1 \%$ $>5 \%$, berarti menerima $\mathrm{H}_{0}$ dan menolak $\mathrm{H}_{1}$.

c. Interpretasi hasil: dengan menerima $\mathrm{H}_{0}$ berarti penerapan metode bermain peran professional pada keterampilan berbicara individual mahasiswa
Gambar 4.1 Data Keterampilan Berbicara Individual Mahasiswa Progdi PBSI

b. Pengujian hipotesis: Karena jenis data dalam penelitian ini adalah ordinal, uji banding variabel keterampilan berbicara individual menggunakan analisis nonparametrik.

Progdi PBSI mencapai nilai 70 dibenarkan. Hal ini didukung pada output rataan empiris 77,67.

d. Ketercapaian Skor Rataan Keterampilan Berbicara Individual

Sebagaimana disebutkan dalam hasil penelitian, skor rataan sebesar 70 telah berhasil dicapai oleh sebagian besar mahasiswa Progdi PBSI melalui metode bermain peran profesional. Skor ini diperoleh dari isian angket pada aspek keterampilan berbicara individual yang meliputi aspek kebahasaan dan nonkebahasaan. Keduanya menunjukkan bahwa 
sebagian besar mahasiswa telah memiliki kemampuan keterampilan berbicara yang baik.

Perolehan skor pada tiap butir di setiap aspek yang diisikan dalam angket menguatkan hal tersebut. Salah satunya adalah bahwa skor terendah, yaitu 2, hanya ditemukan sedikit pada butir tertentu pada setiap aspek. Pada aspek kebahasaan, skor 2 ini hanya ditemukan pada hasil angket dua orang mahasiswa, yaitu pada butir ketepatan pengucapan vokal dan konsonan. Pada aspek nonkebahasaan, skor 2 ini ditemukan pada 3 butir aspek, yaitu 3 skor 2 pada butir keberanian, 2 pada butir kontak mata dan ekspresi, dan 1 pada butir keterbukaan terhadap audiens.

Selain itu, jika dilihat dari pengisian skor sedang, yaitu 3, skor ini tidak banyak ditemukan pada butir penilaian pada tiap aspek. Dari 43 angket sejumlah mahasiswa praktikan, 13 di antaranya menunjukkan skor 3 pada butir pilihan kata; 12 pada butir kontak mata dan ekspresi; dan 12 pada keterbukaan terhadap audiens. Hal ini membuktikan bahwa selain sejumlah butir tersebut, sebagian besar butir penilaian pada setiap aspek yang dinilai menunjukkan skor yang baik, yaitu antara 5-4. Dengan kata lain bahwa kekurangan mahasiswa pada sejumlah butir penilaian itu menjadi gambaran keterampilan berbicara mahasiswa sebagai bagian dari proses menuju tingkat atau predikat yang lebih baik.

Dengan penerapan metode bermain peran profesional, mahasiswa mencapai nilai rata-rata 77,67. Artinya, metode bermain peran merupakan metode yang sesuai untuk diterapkan pada praktik berbicara. Dari hasil pengamatan yang dilakukan dan wawancara mendalam terhadap subjek penelitian, peneliti menyimpulkan beberapa hal yang mendukung ketercapaian hasil tersebut:

a. Meski mahasiswa tampil secara individual, mereka maju secara berkelompok. Hal ini menjadikan mahasiswa lebih berani untuk tampil dan mengekspresikan diri.

b. Metode bermain peran profesional memberikan mahasiswa kesempatan untuk melakukan brainstroming topik berbicara sesuai peran yang diperoleh, baik secara individual maupun kelompok.

c. Metode bermain peran profesional memberikan mahasiswa kesempatan praktik sesuai dengan karakteristik dan tingkat kemampuan yang dimiliki.

d. Metode bermain peran menyajikan langkah pembelajaran yang bersifat komprehensif, mulai dari persiapan hingga evaluasi.

\section{Tahap Pascabicara}

Tahap pascabicara dilaksanakan pada pertemuan ke-5. Dalam tahap pascabicara, mahasiswa mendapatkan evaluasi dari praktik yang telah dilaksanakan. Dari hasil pengamatan dan wawancara yang dilakukan, ditemukan sejumlah persoalan yang dihadapi mahasiswa saat praktik menggunakan metode bermain peran profesional.

a. Grogi

Kecenderungan yang sering terlihat adalah bahwa mahasiswa masih mengalami grogi atau demam panggung. Hal ini dapat dilihat dari gejala yang tampak, seperti berkeringat dingin, overgesture, salah tingkah, kontak mata yang tidak 
mengarah kepada audiens, dan mendadak berhenti berbicara. Rasa grogi tersebut berdampak terhadap kualitas penampilan dan menyebabkan ketidaksesuaian metode berbicara yang dipilih ketika praktik dengan peristiwa, peran, dan tema kegiatan yang sedang ditampilkan.

b. Keterbatasan pengetahuan tentang rambu berbicara di depan publik

Bentuk pelanggaran rambu berbicara yang paling tampak ialah urutan sapaan, bahasa yang kurang sesuai situasi, kurang interaktif, dan ekspresi yang ditampakkan tidak sesuai.

c. Penguasaan kaidah bahasa masih rendah

Kendala praktik berbicara dengan metode bermain peran profesional yang tampak dari mahasiswa ialah penggunaan bahasa yang masih tidak sesuai dengan kaidah. Indikasi yang menunjukan ketidakmaksimalan penguasaan bahasa mahasiswa terlihat dari penggunaan kalimat yang kurang efektif. Misalnya, penggunaan kalimat marilah kita panjatkan puji syukur ke hadiran Tuhan Yang Maha Esa. Pada kalimat tersebut, ketidakefektifan terjadi pada penggunaan kata panjatkan yang menjadikan kalimat ambigu. Untuk menjadi efektif, kalimat tersebut hendaknya diubah menjadi Kita ucapkan syukur kepada Tuhan Yang Maha Esa atau Ucap syukur kita haturkan kepada Tuhan Yang Maha Esa.

Ketidakfektifan bahasa juga tampak pada kalimat para hadirin yang terhormat. Pada kalimat ini, kesalahan terletak pada penggunaan kata para sebelum hadirin sehingga kalimat menjadi boros. Akan lebih baik jika kalimat tersebut diubah menjadi Hadirin yang terhormat atau Hadirin yang berbahagia atau Bapak/Ibu yang terhormat/berbahagia.

Ketidakefektifan bahasa karena kesalahan berbahasa apda tataran fonologi. Kesalahan yang sering muncul adalah pada pengucapan kata republik yang lebih sering diucapkan dengan [repoblik] dibandingkan bentuk benarnya, [republik]. Kesalahan berbahasa lainnya yang sering ditemukan adalah penggunaan kata silakan yang lebih sering diucapkan dengan [silahkan]. Padahal, jika merunut proses morfologisnya, kata dasar yang digunakan adalah sila dan bukan silah sehingga bentuk pengucapan yang tepat adalah [silakan].

d. Ketidaksesuaian situasi dengan intonasi bicara

Mahasiswa masih sering menggunakan intonasi yang tidak sesuai dengan situasi bicara yang tengah dijalaninya. Termasuk pula jika dikaitkan dengan interaksi pembicara pada audiens, terutama dari arah pandang. Pembicara cenderung menunduk atau menatap ke satu arah sehingga seakan-akan ia berbicara dengan dan untuk dirinya sendiri.

e. Minimnya sarana dan prasarana pendukung

Pelaksanaan praktik berbicara dengan metode bermain peran profesional terkendala oleh ketersediaan sarana dan prasarana. Mahasiswa tidak maksimal dalam melaksanakan praktik, khususnya dalam mem- 
bangun situasi berbicara, karena beberapa sarana pendukung tidak tersedia, seperti pelantang, podium, dan meja panjang.

f. Ekspresi belum sesuai konteks praktik

Mengenai ekspresi, banyak dari praktikan yang masih menunjukkan ekspresi yang kurang atau bahkan tidak sesuai. Misalnya, suasana bicara yang dipraktikkan adalah suasana meriah, eskpresi yang ditampilkan masih datar dan terlalu monoton. Sebaliknya, ada pula yang praktikan yang berbicara pada suasana serius, misalnya, suasana khikmat atau khusuk, tetapi ekspresi yang ditampilkan justru ekspresi bahagia.

\section{PENUTUP}

\section{SIMPULAN}

Berdasarkan hasil analisis data dan sejumlah pembahasannya, penelitian ini menyimpulkan dua hal. Hasil pertama berkaitan dengan penerapan metode bermain peran profesional. Hasil tersebut menunjukkan bahwa penerapan metode bermain peran profesional dilaksanakan dalam lima pertemuan yang di dalamnya meliputi tiga tahap. Ketiga tahap tersebut, yaitu tahap prabicara, bicara, dan pascabicara. Pada penerapannya, penilaian keterampilan berbicara pada mahasiswa Progdi PBSI berhasil mencapai nilai rataan, yaitu 70 dengan nilai capaian rata-rata $77,67 \%$. Artinya, metode bermain peran sesuai jika diterapkan untuk praktik berbicara individual. Hal ini menunjukkan bahwa mahasiswa Progdi PBSI memiliki keterampilan berbicara yang bagus, baik dari segi kebahasan maupun nonkebahasaan.

Dalam praktiknya, ditemukan sejumlah kekurangan, di antaranya 1) mahasiswa masih demam panggung; 2) pengetahuan mahasiswa mengenai rambu berbicara di depan publik masih terbatas; 3) penguasaan kaidah bahasa masih rendah; 4) keterampilan penggunaan intonasi masih rendah; 5) kesesuaian ekspresi masih kurang, dan 6) minimnya sarana dan prasarana pendukung.

Hasil kedua, berkaitan dengan pengembangan karakter antikorupi. Hasil tersebut menunjukkan bahwa penerapan pembelajaran keterampilan bericara dengan metode bermain peran profesional telah berhasil meningkatkan keterampilan berbicara individual dan telah berhasil memperlihatkan, mengembangkan, dan membudayakan karakter antikorupsi mahasiswa Progdi PBSI.

\section{SARAN}

Berdasarkan simpulan yang telah dipaparkan sebelumnya, saran yang dapat diberikan sehubungan dengan hasil penelitian tersebut adalah bahwa perlu kiranya ada penelitian lebih lanjut untuk menggunakan metode bermain peran profesional untuk meningkatkan prestasi belajar pada topik atau materi yang lain.

\section{DAFTAR PUSTAKA}

Abidin, Yunus. 2013. Pembelajaran Bahasa Berbasis Pendidikan Karakter. Bandung: Refika Aditama.

Arikunto, Suharsimi. 2006. Prosedur Penelitian: Suatu Pendekatan Praktis. Jakarta : Rineka Cipta.

2010. Prosedur Penelitian : Suatu Pendekatan Praktis. Jakarta: Rineka Cipta. 
Arsyad, Maidar G., dan Mukti U.S. 1988. Pembinaan Kemampuan Berbicara Bahasa Indonesia. Jakarta: FPBS IKIP Jakarta.

Brown, H. Douglas. 2008. Prinsip Pembelajaran dan Pengajaran Bahasa (edisi kelima). Jakarta: Kedutaan Besar Amerika untuk Indonesia.

Dharma, Budi. 2004. "Korupsi dan Budaya". Harian Kompas, 25/10/2003.

Dunar, Hilbram. 2015. My Public Speaking. Jakarta: Gramedia.

Harmanto. 2008. "Mencari Model Pendidikan Antikorupsi Bagi Siswa SMP dan MTs”. Makalah disajikan dalam Simposium Nasional Pendidikan Tahun 2008.

Iskandarwassid dan Dadang Sunendar. 2008. Strategi Pembelajaran Bahasa. Bandung: Rosdakarya.

Mahardika, Deni. 2015. Cerdas Berbicara di Depan Publik: Beragam Tips Menumbuhkan Rasa Percaya Diri. Yogyakarta: Flassbooks.
Moleong, Lexy J. 2010. Metodologi Penelitian Kualitatif. Bandung: Rosdakarya.

Mulyasa, E. 2011. Menjadi Guru Profesional: Menciptakan Pembelajaran Kreatif dan Menyenangkan. $\quad$ Bandung: Remaja Rosdakarya.

Rahman, Fathur. 2009. "Kajian Evaluatif Implementasi Problem Based Learning dalam Pendidikan Antikorupsi di Beberapa Perguruan Tinggi Yogyakarta”. Yogyakarta: UNY.

Sardiman, A.M. 2014. Interaksi dan Motivasi Belajar Mengajar. Jakarta: Raja Grafindo Persada.

Sudjana, Nana. 2009. Dasar-dasar Proses Belajar Mengajar. Bandung: Sinar Baru Algesindo.

Sugiyono. 2014. Metode Penelitian Pendidikan: Pendekatan Kuantitatif, Kualitatif dan $R$ and $D$. Bandung: Alfabeta.

Tim Penyusun. 2011. Pendidikan Antikorupsi untuk Perguruan Tinggi. Jakarta: Kementrian Pendidikan dan Kebudayaan RI Direktorat Jenderal Pendidikan Tinggi. 